\title{
BEHAVIOR AND DURABILITY OF HIGH AND ULTRA HIGH STRENGTH CONCRETE MANUFACTURED BY LOCAL MATERIALS
}

\author{
Walid Safwat El- Sayed', Dina M. Sadek', and Amr \\ Basuoni Ibrahim Al- Samahy ${ }^{3}$ \\ ${ }^{1}$ Associate Professor, Suez Canal University, Suez, Egypt \\ ${ }^{2}$ Researcher, Housing and Building National Research Center, Giza, Egypt \\ ${ }^{3}$ Department of Civil and Architectural construction, Suez Canal \\ University, Egypt
}

(Received May 29, 2011 Accepted June 26, 2011)

Concrete has undergone rapid and phenomenal development in recent decades. Today, new classes of concretes (i.e., high strength, very high strength and ultra high strength concretes) has been manufactured and transferred from laboratory research to practical application. These concretes are used increasingly and replaced normal strength concrete in many structural applications. Although the mechanical properties and durability of normal strength concrete has been well evaluated, these properties of the new classes of concretes as well as the relationship between the compressive strength and other mechanical properties as well as the durability of concrete are not well identified.

In this paper, different classes of concrete with a wide range of compressive strength (250 to $1000 \mathrm{~kg} / \mathrm{cm} 2)$ are manufactured using local materials and their mechanical properties as well as their durabilityrelated properties are determined. Furthermore, the mathematical relationships between the compressive strength and other properties are developed using statistical methods.

The experimental results showed that it is possible to produce concrete with compressive strength in excess of $1000 \mathrm{~kg} / \mathrm{cm} 2$ using local materials in Egypt. Furthermore, the suggested mathematical equations can be used to derive the properties of concrete based on its compressive strength.

KEYWORDS: Compressive strength; High strength concrete; Very high strength concrete; Ultra high strength concrete; Mechanical properties; Durability.

\section{INTRODUCTION}

Concrete has been one of the most widely used building materials because of its compressive strength, low cost, its ability to be easily formed and placed according to need and good combination with other materials especially with steel. It is estimated that the present yearly worldwide consumption of concrete is about 12 billion tones. In 1930, when prestressing has introduced, the importance of using high strength concrete to withstand the high compressive stresses developed due to prestressing was recognized. This naturally led to the development of concrete with compressive 
strength ranging from 300 to $700 \mathrm{~kg} / \mathrm{cm}^{2}$. After the Second World War, a large amount of concrete was used in construction. Since that time, there has been a continuous effort to produce stronger and more durable concrete. Recent developments in the field of concrete mix design have indicated that it is possible to produce concrete, which has 28-days compressive strength ranging from 700 to $1000 \mathrm{~kg} / \mathrm{cm}^{2}[1,2]$. Now, new classes of concretes such as very high strength and ultra high strength concrete have surged ahead as the more superior cement based materials. According to the American Concrete Institute, high strength concrete is a type of concrete with 28-days compressive strength greater than $42 \mathrm{MPa}$ [3]. Maiti et al., [4] defined very high strength concrete as the concrete with compressive strength greater than $80 \mathrm{MPa}$. Hela et al., [5] defined ultra high strength concrete as a concrete with compressive strength between $100 \mathrm{MPa}$ and $200 \mathrm{MPa}$.

As a result of the superior strength of high strength, very high strength and ultra high strength concrete, they are used in various applications such as in industrial and nuclear waste storage facilities, high-rise buildings, bridges, prestressed and precast concrete members, roofs, piers, dams, grandstand roofs, marine foundations, parking garages, and heavy duty industrial floors, long-span girders, thin-walled tunnel liners, and blast-resistant barriers and structures, shells and seismic-resistant structures [6-9].

Comparatively speaking, greater emphasis is usually paid to the strength and workability of the concrete while durability has not been given much attention in the mix design. Consequently, series problems arise from the durability such as deterioration, corrosion, bleeding, efflorescence or cracks that are commonly found in many buildings within a few years after construction. Theses problems are signs of aging caused by the neglect of durability in the concrete design. Gradual deterioration caused by the lack of durability reduces the safety margin of concrete structures to an extent that serious concerns have been raised. It is estimated that over $40 \%$ of the total resources of the building industry are applied to repair and maintenance of existing structures [10].

The general aim of this paper is to produce different types of concrete namely; normal strength concrete (NSC), high strength concrete (HSC), very high strength concrete (VHSC) and ultra high strength concrete (UHSC), using locally available materials in Egypt as well as the evaluation of their mechanical properties (compressive strength, tensile strength and flexural strength) as well as their durability performance (abrasion resistance, absorption and permeability).

\section{EXPERIMENTAL PROCEDURE}

\subsection{Materials}

Cement, dolomite, sand, silica fume, tap-drinking water and chemical admixture were used in the experimental work. All the used materials were selected from local sources in Egypt. The physical, chemical and mechanical properties of the used materials were determined according to Egyptian Specifications.

The used cement was produced by El-Suez Cement Company designated as CEM I 42.5 N. A commercial silica fume (SF) was purchased locally from Metallurgical \& Construction Chemicals Company to be used as a mineral additive. 
The properties of cement and silica fume are given in table 1 . The fine aggregate was local natural sand and the coarse aggregate was crushed dolomite with nominal maximum size of $10 \mathrm{~mm}$. The properties of aggregates are given in table 2 . Superplasticizer (SP) was used to lower the water/cementitious ratio and increase the slump. It was mixed with water before being added to concrete mix. The used admixture was ADDICRETE BVF from chemicals modern building company.

\subsection{Concrete mixes}

Trial mixes were cast to produce normal strength concrete, high strength concrete, very high strength concrete and ultra high strength concrete mixes with the target 28-days compressive strengths in the range shown in table 3 . All concrete mixes were designed using absolute volume method, with cement content varied from 400 to $600 \mathrm{~kg} / \mathrm{m}^{3}, 0 \%$ or $10 \%$ silica fume (by weight of cement) as an addition, sand/total aggregate ratio of $40 \%$, w/c ratio varied from 0.26 to 0.57 , and a superplasticizer admixture used in high, very high and ultra high strength concrete mixes to maintain a target slump of $10 \pm 2$ $\mathrm{cm}$. Its dose varied from $0 \%$ to $4 \%$ by weight of cement. Table 4 shows the mix proportions details for the selected mixes.

Table 1. Chemical, physical and mechanical properties of cement and SF

\begin{tabular}{|c|c|c|c|c|}
\hline \multicolumn{3}{|c|}{ Component/property } & Cement & SF \\
\hline \multirow{6}{*}{ 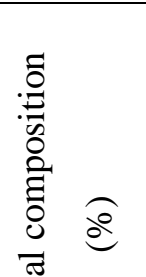 } & \multicolumn{2}{|l|}{$\mathrm{SiO}_{2}$} & 21.0 & 96.39 \\
\hline & \multicolumn{2}{|l|}{$\mathrm{Al}_{2} \mathrm{O}_{3}$} & 6.1 & 0.65 \\
\hline & \multicolumn{2}{|l|}{$\mathrm{Fe}_{2} \mathrm{O}_{3}$} & 3.0 & 0.33 \\
\hline & \multicolumn{2}{|l|}{$\mathrm{CaO}$} & 61.5 & 0.62 \\
\hline & \multicolumn{2}{|l|}{$\mathrm{MgO}$} & 2.1 & 0.04 \\
\hline & \multicolumn{2}{|l|}{$\mathrm{K}_{2} \mathrm{O}$} & 0.3 & 0.37 \\
\hline \multirow{4}{*}{ 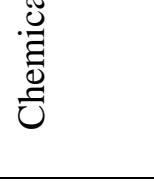 } & \multicolumn{2}{|l|}{$\mathrm{SO}_{3}$} & 2.5 & 0.05 \\
\hline & \multicolumn{2}{|l|}{$\mathrm{Na}_{2} \mathrm{O}$} & - & 0.2 \\
\hline & \multicolumn{2}{|l|}{ Loss on ignition } & 2.4 & 1.34 \\
\hline & \multicolumn{2}{|l|}{ Insoluble residue } & 0.9 & - \\
\hline \multirow{7}{*}{ 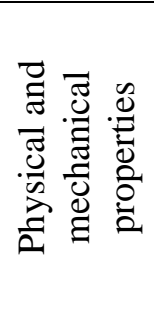 } & \multirow{2}{*}{\multicolumn{2}{|c|}{$\begin{array}{c}\text { Specific gravity } \\
\text { Specific surface area }\left(\mathrm{cm}^{2} / \mathrm{g}\right)\end{array}$}} & 3.15 & 2.15 \\
\hline & & & 3,550 & 264,500 \\
\hline & \multirow{2}{*}{ Setting time (min.) } & Initial & 135 & - \\
\hline & & Final & 195 & - \\
\hline & \multicolumn{2}{|l|}{ Soundness (mm) } & 1 & - \\
\hline & \multirow{2}{*}{ Compressive strength $\left(\mathrm{N} / \mathrm{mm}^{2}\right)$} & 2-days & 26.2 & - \\
\hline & & 28-days & 48.6 & - \\
\hline
\end{tabular}

\subsection{Specimens casting curing and testing}

Concrete mixes were cast in the laboratory of Housing and Building National Research Center. The slump test was conducted immediately after mixing. For each concrete mix, $10 \mathrm{~cm}$ size cubes were cast to determine the compressive strength and unit weight, cylinders of $15 \mathrm{~cm}$ diameter and $30 \mathrm{~cm}$ height were used in splitting tensile test, prismatic specimens with a square section of $10 \mathrm{~cm}$ side and a length of $50 \mathrm{~cm}$ were used in flexural test and Cylindrical specimens of $15 \mathrm{~cm}$ diameter and $15 \mathrm{~cm}$ height 
were used in permeability test. Disks of $15 \mathrm{~cm}$ diameter and $5 \mathrm{~cm}$ height were cut from the cylindrical specimens and used to determine the absorption of water. Prisms of $7 \times 7 \times 2 \mathrm{~cm}$ were cut from the cubes and used in abrasion resistance test.

Table 2. Basic properties of aggregates

\begin{tabular}{|c|c|c|}
\hline Property & Coarse aggregate & Fine aggregate \\
\hline Specific gravity (SSD) & 2.70 & 2.50 \\
\hline Unit weight ( $\left.\mathrm{t} / \mathrm{m}^{3}\right)$ & 1.67 & 1.62 \\
\hline Absorption (\%) & 1.53 & - \\
\hline Clay and other fine materials (\%) & 0.12 & 1.4 \\
\hline Impact index (\%) & 14.6 & - \\
\hline Flakiness index (\%) & 14.3 & - \\
\hline Elongation index (\%) & 16.6 & - \\
\hline Abrasion resistance (\%) & 18.4 & - \\
\hline
\end{tabular}

Table 3. Target compressive strength

\begin{tabular}{|l|c|}
\hline Type of concrete & Range of target \\
\hline Normal strength concrete & $250-350$ \\
\hline High strength concrete & $450-650$ \\
\hline Very high strength concrete & $800-1000$ \\
\hline Ultra high strength concrete & $>1000$ \\
\hline
\end{tabular}

Table 4. Concrete mixtures proportions

\begin{tabular}{|c|c|c|c|c|c|c|c|c|c|c|c|}
\hline Mix & Concrete & Quantit & ties of Com & pound 1 & Mater & ials $(\mathrm{Kg} / 1$ & & \multirow{2}{*}{\multicolumn{2}{|c|}{$\mathrm{w} / \mathrm{c}^{1} \mathrm{w} / \mathrm{b}^{2}$}} & \multirow{2}{*}{$\begin{array}{c}\text { Slump } \\
(\mathrm{cm})\end{array}$} & \multirow{2}{*}{\begin{tabular}{|c|} 
Curing \\
condition
\end{tabular}} \\
\hline ID & type & Cement & Silica fume & Water & Sand & Dolomit & SP & & & & \\
\hline 1 & \multirow{2}{*}{$\begin{array}{l}\text { Normal } \\
\text { strength } \\
\text { concrete }\end{array}$} & 350 & - & 199.5 & 721 & 1082 & 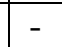 & 0.57 & 0.57 & 12 & \multirow{5}{*}{$\begin{array}{l}\text { Water } \\
\text { curing } \\
\text { for } 28 \\
\text { days }\end{array}$} \\
\hline 2 & & 400 & - & 200 & 704 & 1056 & - & 0.50 & 0.50 & 10 & \\
\hline 3 & High & 400 & - & 160 & 741 & 1111 & 6 & 0.40 & 0.40 & 8.5 & \\
\hline 4 & $\begin{array}{l}\text { strength } \\
\text { concrete }\end{array}$ & 400 & 40 & 160 & 719 & 1078 & 9 & 0.40 & 0.36 & 8 & \\
\hline 5 & Very & 500 & 50 & 150 & 681 & 1022 & 20 & 0.30 & 0.27 & 8.5 & \\
\hline 6 & $\begin{array}{c}\text { high } \\
\text { strength }\end{array}$ & 500 & 50 & 150 & 681 & 1022 & 20 & 0.30 & 0.27 & 8.5 & Steam \\
\hline 7 & $\begin{array}{c}\text { Ultra } \\
\text { high } \\
\text { strength } \\
\text { concrete }\end{array}$ & 600 & 60 & 156 & 634 & 951 & 22 & 0.26 & 0.24 & 9 & $\begin{array}{c}\text { curıng } \\
\text { for } 3 \\
\text { days then } \\
\text { water } \\
\text { curing }\end{array}$ \\
\hline
\end{tabular}

w/c: water to cement ratio

${ }^{2} \mathrm{w} / \mathrm{b}$ : water to binder (cement + silica fume) ratio

All specimens were cast in steel moulds and hand compacted. After 24 hours of casting, the specimens were demoluded and transferred to curing regimes. Two 
techniques of curing were applied. The first curing technique was the standard moist curing that the specimens were immersed in water at $22^{\circ} \mathrm{C}$ until the age of testing. The second curing technique was the steam curing that the specimens were cured at $75^{\circ} \mathrm{C}$ for three days in a container over water, and then they were water-cured until the age of testing.

All the tests were carried out at age of 28 days. Compression, splitting tensile and flexural tests were carried out according to the Egyptian Standard Specifications No.1658 while the abrasion resistance test was carried out according to the Egyptian Standard Specifications No. 269/2003. In absorption test, the absorption of concrete was the ratio between the mass of absorbed water to the dry mass of specimen. The water permeability of concrete was measured by using "Automatic Concrete Water Permeability Apparatus". The specimens were subjected to hydrostatic stress for a period of 5 hours. The amount of water passing through a given thickness of the specimen in a given time was measured. The coefficient of water permeability was determined from Darcy's law as follows:

$K=\frac{C C \times h}{A \times T \times P}$

Where K: permeability coefficient $(\mathrm{cm} / \mathrm{sec}), \mathrm{CC}$ : permeated water $\left(\mathrm{cm}^{3}\right)$, h: height of the specimen $(\mathrm{cm})$, A: surface area of the specimen $\left(\mathrm{cm}^{2}\right)$, T: time for water to permeate through the specimen ( $\mathrm{sec}$ ) and P: hydrostatic pressure ( $\mathrm{cm}$ of water column).

\section{RESULTS AND DISCUSSION}

\subsection{Compressive strength}

Compressive strength of concrete is considered the most important property. Many other engineering properties of concrete related to its compressive strength. Fig.1 shows the compressive strength of concrete mixes after 28 days, it was found that compressive strength of concrete increases by increasing the content of cement. The compressive strength increased about $33 \%$ with increasing cement content from 350 $\mathrm{kg} / \mathrm{m}^{3}$ to $400 \mathrm{~kg} / \mathrm{m}^{3}$ in the comparison between mix 1 and 2 . As expected at the same cement content and curing technique, compressive strength is inversely proportional to w/c ratio. Compressive strength increased significantly $(\sim 38 \%)$ by decreasing w/c ratio from 0.5 to 0.4 in the comparison between mix 2 and 3 . This is due to that at higher w/c ratio, the paste is more porous and hence the strength is lower. Furthermore, the addition of silica fume to concrete along with the use of a sufficient amount of superplasticizer significantly increases its compressive strength compared to plain concrete (i.e., without silica fume). Compressive strength increased by about $34 \%$ by adding silica fume to concrete in the comparison between mix 3 and 4 . This increase is due to the physical and chemical effect of silica fume that it contributes to the hydration reaction between Portland cement and water by reacting with the calcium hydroxide to produce additional calcium silicate hydrate gel leading to enhancement in strength.

The second role played by silica fume is altering the matrix structure of the concrete that its extremely small particles occupy the voids between the cement grains, acting as filler, reducing the porosity of the bulk cement matrix and resulting in a dense 
structure [11-12]. Moreover, steam curing increases the compressive strength as compared to standard moist curing especially in concrete containing mineral admixtures such as silica fume. Compressive strength increased by about $16 \%$ by using steam curing instead of standard moist curing in the comparison between mix 5 and 6 . The same findings were reported by Yazıc1 [8] that steam curing improved the compressive strength of all specimens compared to standard curing and the increase was between 25-63\% depending on the type and content of the used mineral admixture. It is clear that steam curing provides perfect conditions for complete and accelerated hydration media for hydration process especially with combined mineral admixtures.

It is clear that it is possible to produce UHSC, with compressive strength in excess of $1000 \mathrm{~kg} / \mathrm{cm}^{2}$ after 28-days of curing using local materials if these materials are carefully selected and properly mixed, taking into account the content of cement, w/c ratio, using of chemical and mineral admixtures, and curing technique.

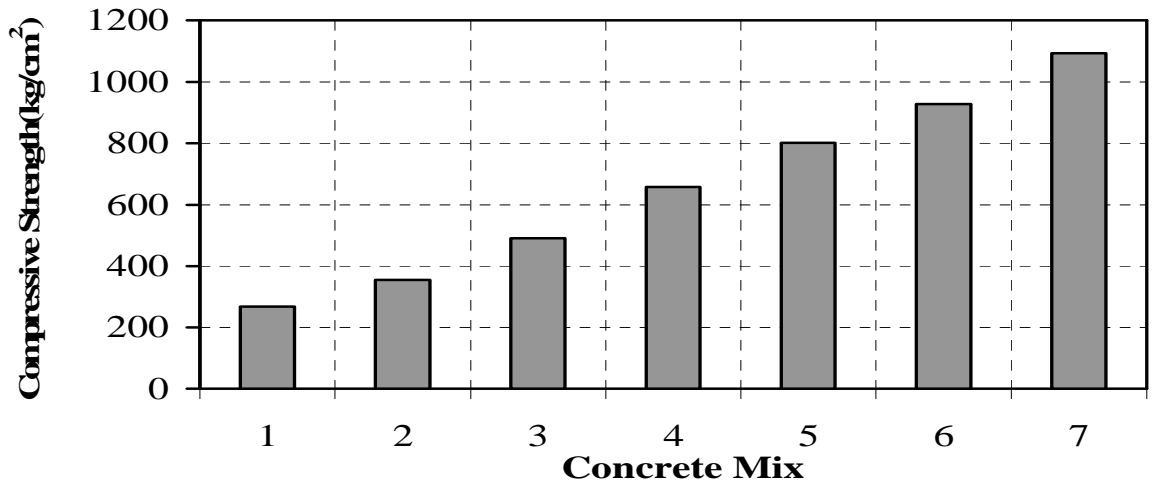

Fig. 1. Compressive strength of concrete mixes

\subsection{Splitting tensile strength}

The splitting tensile strength for various concrete mixes is shown in fig. 2. It was found that concrete tensile strength increases by increasing the content of cement. Tensile strength increased by about $7 \%$ with increasing the content of cement from $350 \mathrm{~kg} / \mathrm{m}^{3}$ to $400 \mathrm{~kg} / \mathrm{m}^{3}$ in the comparison between mix 1 and 2 . Tensile strength increased significantly (i.e., $8.2 \%$ ) by decreasing w/c ratio from 0.5 to 0.4 in the comparison between mix 2 and 3 . The addition of silica fume to concrete along with the use of a sufficient amount of superplasticizer significantly increases the tensile strength compared to plain concrete. Tensile strength increased by $8.3 \%$ by adding $10 \%$ silica fume to concrete in the comparison between mix 3 and 4 . Tensile strength increased by $8.1 \%$ by using steam curing instead of standard moist curing in the comparison between mix 5 and 6 .

The relationship between the splitting tensile strength/compressive strength ratio and the corresponding compressive strength is shown in fig. 3. It can be found that the ratio between the tensile strength and compressive strength of concrete is not unique but depends on the compressive strength; the higher the compressive strength, the lower the ratio. The ratio between the splitting tensile strength and the corresponding compressive strength was in the range of 10.6-13.3\%, 6.7-8.3\% and 5.9- 
$6.3 \%$ for the produced NSC, HSC and VHSC, respectively. For UHSC it was $5.5 \%$. Dewar [3] reported that at low strengths, the splitting tensile strength may be as high as $10 \%$ of the compressive strength but at higher strengths it may reduce to $5 \%$.

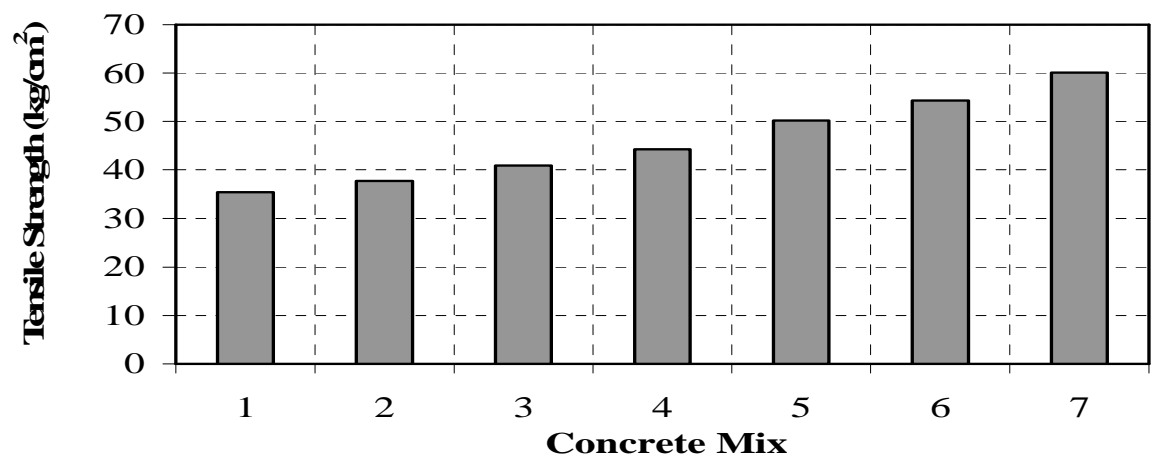

Fig. 2. Splitting tensile strength of concrete mixes

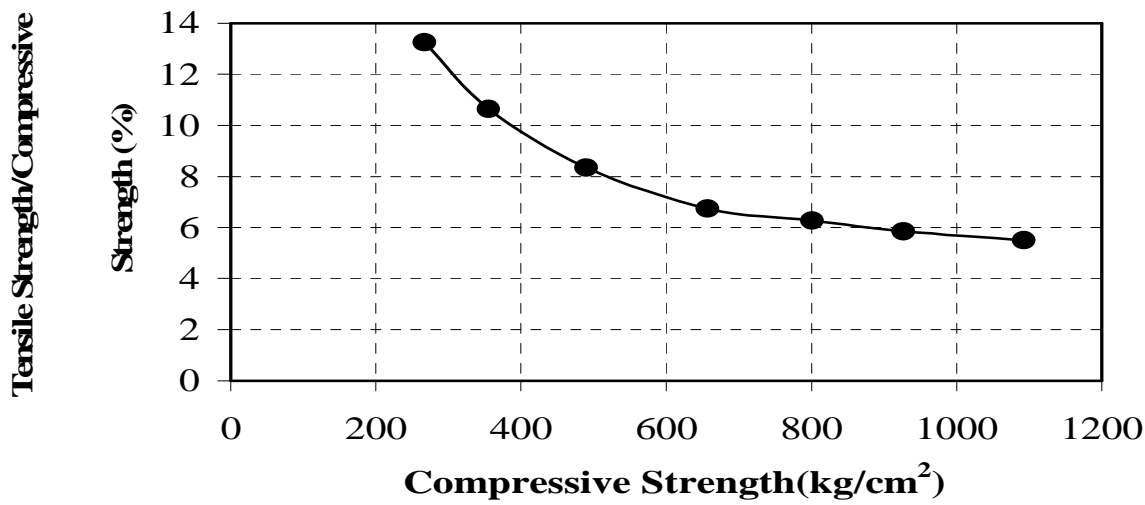

Fig. 3. Relationship between tensile strength/compressive strength ratio and compressive strength

A mathematical relationship between the splitting tensile strength and compressive strength was suggested as follows:
$f_{\mathrm{t}}=1 \mathrm{E}-5 f_{\mathrm{c}}{ }^{2}+0.0138 f_{\mathrm{c}}+\mathbf{3 1 . 0 7 9}$
for $265 \mathrm{~kg} / \mathrm{cm}^{2}<\mathrm{f}_{\mathrm{c}}<1100 \mathrm{~kg} / \mathrm{cm}^{2}$

Where $\mathrm{f}_{\mathrm{c}}$ : the 28-days cube compressive strength $\left(\mathrm{kg} / \mathrm{cm}^{2}\right)$ of concrete and $\mathrm{f}_{\mathrm{t}}$ : the 28-days splitting tensile strength $\left(\mathrm{kg} / \mathrm{cm}^{2}\right)$.

It is clear that the tensile strength is proportional to compressive strength; the higher the compressive strength, the higher the tensile strength. Comparing the suggested equation with that set out in ACI 363R-92 [3] for compressive strength in the range of $210-830 \mathrm{~kg} / \mathrm{cm}^{2}$, it can be found that the suggested equation for the relationship between tensile and compressive strength is very close to the ACI 363R-92 equation in (Fig. 4). 


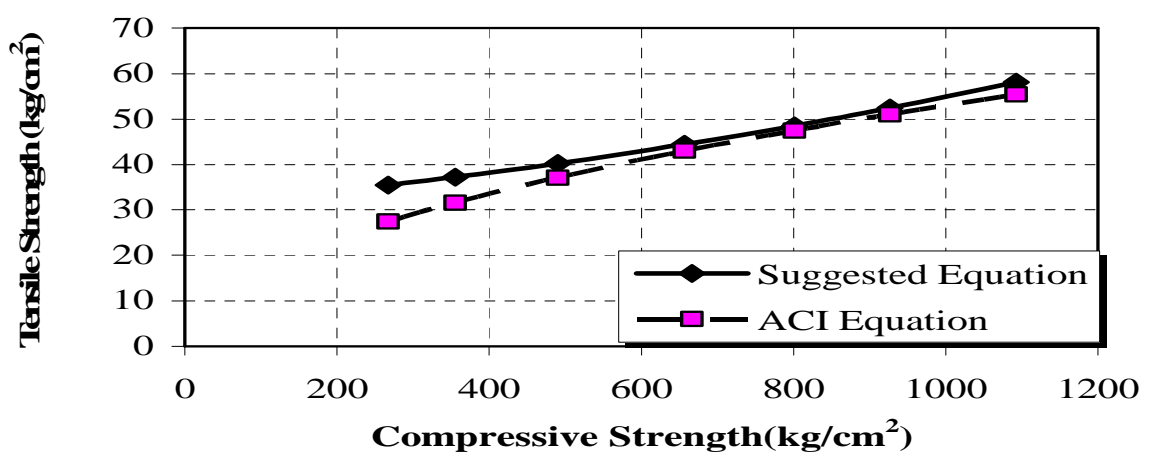

Fig. 4. Suggested equation and ACI equation for tensile and compressive strength relationship

\subsection{Flexural strength}

The flexural strength for concrete mixes is shown in fig. 5. It was found that the flexural strength increased by $8.2 \%$ with increasing cement content from $350 \mathrm{~kg} / \mathrm{m}^{3}$ to $400 \mathrm{~kg} / \mathrm{m}^{3}$ in the comparison between mix 1 and 2 . The flexural strength increased by $8.5 \%$ with decreasing w/c ratio from 0.5 to 0.4 in the comparison between mix 2 and 3 . The addition of silica fume to concrete along with the use of a sufficient amount of superplasticizer increases the flexural strength compared to plain concrete, and the increase in flexural strength was about $8.3 \%$ by adding $10 \%$ silica fume to concrete in the comparison between mix 3 and 4 . Steam curing increases the flexural strength as compared to standard moist curing especially in concrete containing mineral admixtures such as silica fume. The flexural strength increased by $10.4 \%$ by using steam curing instead of standard moist curing in the comparison between mix 5 and 6 . The relationship between flexural strength/compressive strength and the corresponding compressive strength is shown in fig. 6 . It can be found that the ratio between the flexural strength and compressive strength of concrete is not constant but depends on the compressive strength; the higher the compressive strength, the lower the ratio. The ratio between the flexural strength and the corresponding compressive strength was in the range $20-24.6 \%, 14.9-15.8 \%$ and $13.7-14.4 \%$ for the two produced NSC, HSC and VHSC, respectively, while it was $12.9 \%$ for UHSC. Arafa et al. [6] found that the flexural strength is about $9 \%$ of the compressive strength.

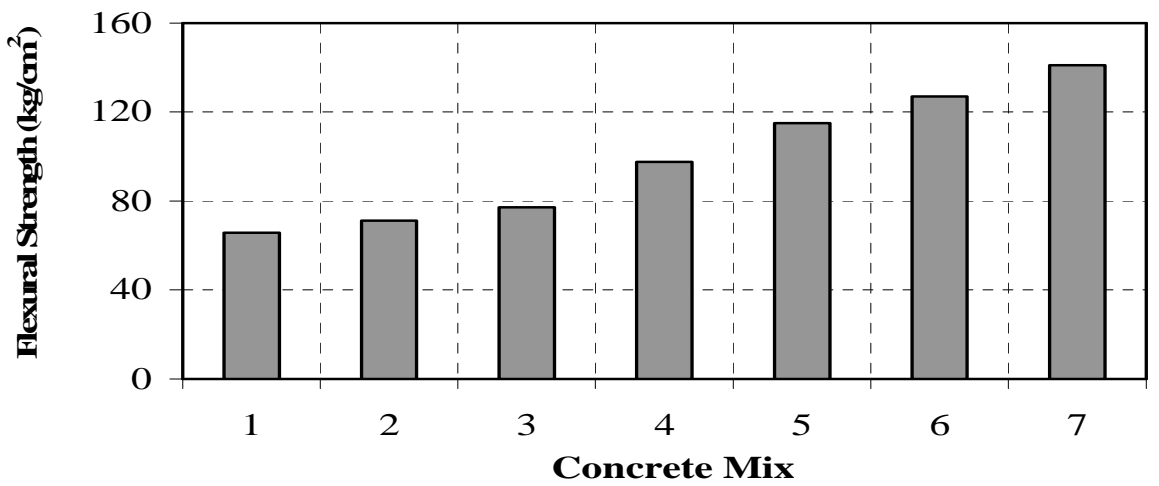

Fig. 5. Flexural strength of concrete mixes 


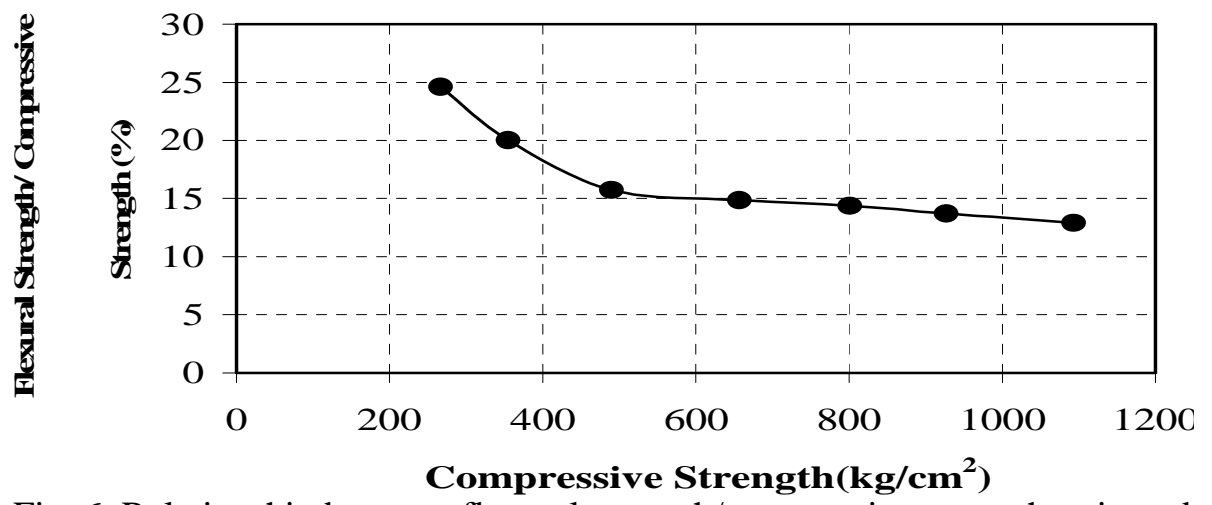

Fig. 6. Relationship between flexural strength/compressive strength ratio and compressive strength

A mathematical relationship between the flexural strength and compressive strength was suggested as follows:

$f_{\mathrm{r}}=-\mathbf{2 E}-7 \boldsymbol{f}_{\mathrm{c}}{ }^{3}+\mathbf{0 . 0 0 0 4} \boldsymbol{f}_{\mathrm{c}}{ }^{2} \mathbf{- 0 . 1 8 9 4} \boldsymbol{f}_{\mathrm{c}}+\mathbf{8 9 . 2 5 8}$ for $265 \mathrm{~kg} / \mathrm{cm}^{2}<\mathrm{f}_{\mathrm{c}}<1100 \mathrm{~kg} / \mathrm{cm}^{2}$

Where $\mathrm{f}_{\mathrm{c}}$ : the 28-days cube compressive strength $\left(\mathrm{kg} / \mathrm{cm}^{2}\right)$ of concrete and $\mathrm{f}_{\mathrm{r}}$ : the 28-days flexural strength $\left(\mathrm{kg} / \mathrm{cm}^{2}\right)$.

Comparing the flexural strength obtained from the suggested equation with that obtained from the equation set out in ACI 363R-92 [3] for compressive strength in the range $210-830 \mathrm{~kg} / \mathrm{cm}^{2}$, it can be found that the ACI equation underestimates the flexural strength of concrete (Fig. 7).

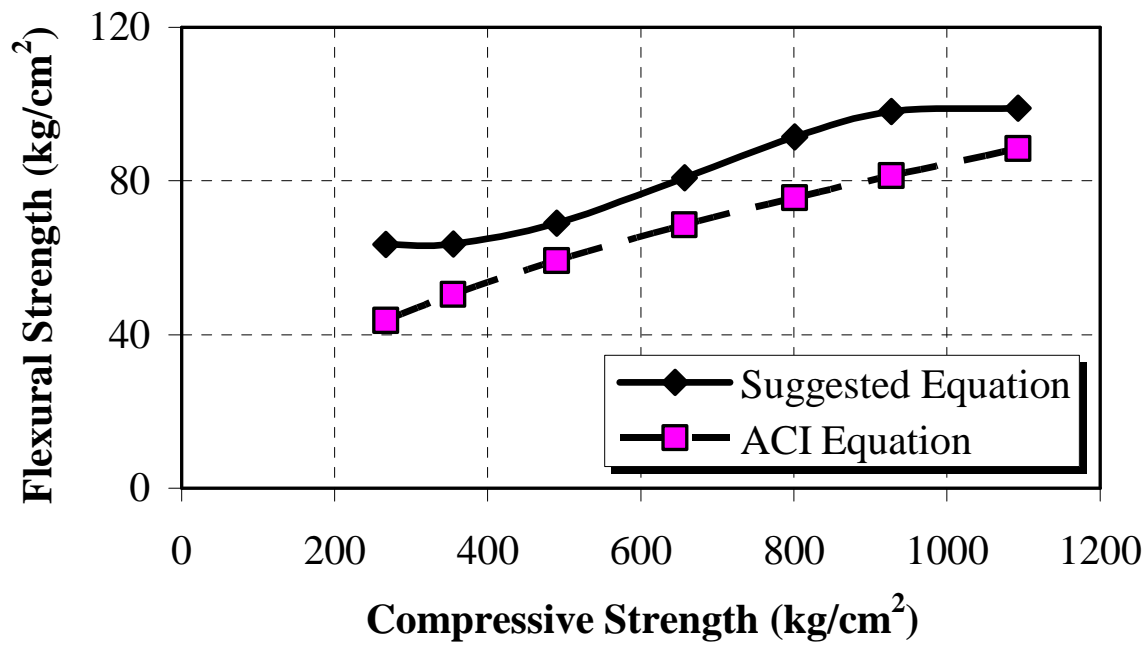

Fig. 7. Suggested equation and ACI equation for flexural strength and compressive strength relationship

\subsection{Permeability}

The permeability of concrete is a key factor influencing the durability of concrete. It is particularly important in reinforced concrete because the concrete must prevent water from reaching the reinforcement. Generally, permeability is defined as "The flow of a fluid through a material under a pressure gradient" [13]. The water permeability test results for concrete mixes are shown in fig. 8. It was found that as expected, the 
permeability of concrete decreases by increasing the content of cement. It decreased by $29.2 \%$ with increasing cement content from 350 to $400 \mathrm{~kg} / \mathrm{m}^{3}$ (mix 1 and 2). The permeability coefficient decreases significantly by decreasing w/c ratio. It decreased by $44.1 \%$ by decreasing w/c ratio from 0.5 to 0.4 in the comparison between mix 2 and 3 . This decrease may be due to the fact that concrete permeability is dependent on permeability of each constituent material and its geometric arrangement. The permeability of cement paste is primarily related to pore structure, which includes porosity, pore size and connectivity. It was demonstrated that a decrease in the w/c ratio is accompanied by lower porosity. A decrease in the porosity means that the there is a decrease in pore size and a disconnection among pores, and so water cannot flow any more through them. Hence, the permeability of concrete decreases accordingly [14]. In comparison between concrete mixes 3 and 4, it can be found that the permeability decreased $48.4 \%$ by using silica fume. This decrease is due to the physical and chemical effect of silica as illustrated previously leading to pore refinement and a densified structure of the concrete as well as the improvement in the interfacial transition zone thus reducing the porosity of the bulk cement matrix [14]. The permeability decreases by using steam curing instead of moist curing. It decreased by $36.9 \%$ by using steam curing technique instead of standard moist curing (mix 5 and $6)$. It is known that, at temperatures greater than those normally experienced in the laboratory, the rate of the pozzolanic reaction increases leading to a greater degree of hydration and denser microstructure and therefore decreases the permeability [8].

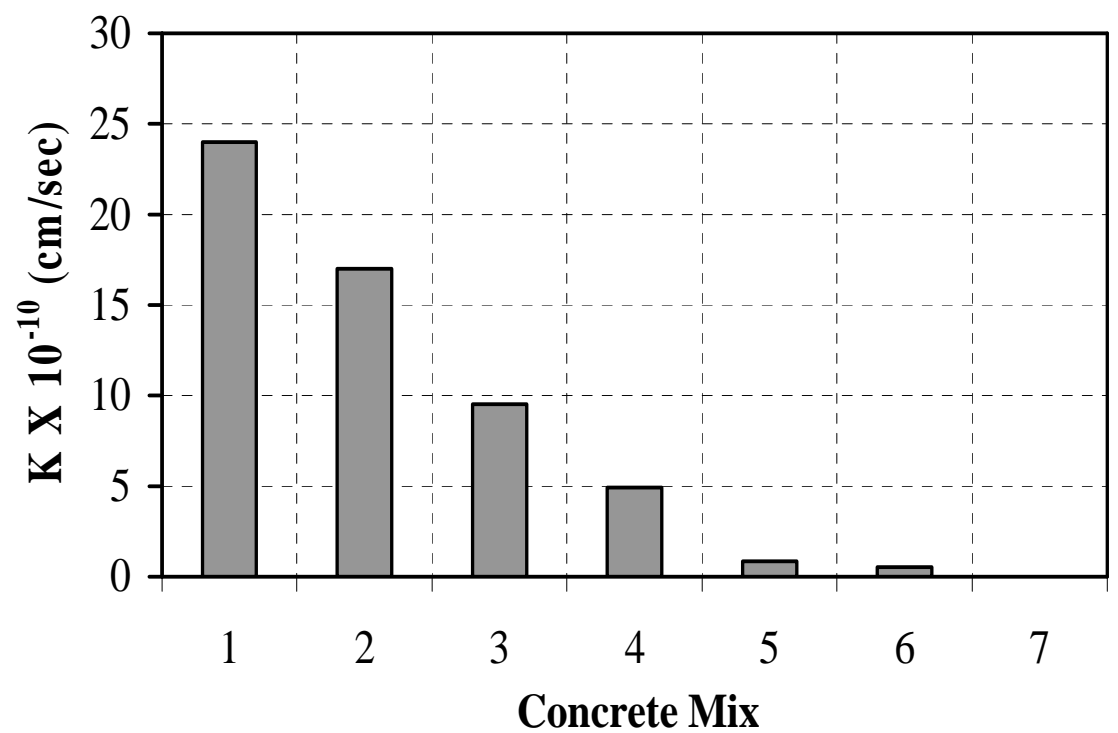

Fig. 8. The permeability of concrete mixes

It can be concluded from the above that using $10 \%$ silica fume as an addition is considered the most important factor influencing the permeability of the concrete followed by w/c ratio, curing technique, and finally the content of cement.

A mathematical relationship between the water permeability and compressive strength of concrete was suggested as follows:

$\mathrm{K}=\left[\mathbf{5 E}-5 f_{c}{ }^{2}-\mathbf{0 . 0 9 3 3} f_{c}+\mathbf{4 4 . 6 2 3}\right] \times \mathbf{1 0}^{-10} \quad$ for $265 \mathrm{~kg} / \mathrm{cm}^{2}<\mathrm{f}_{\mathrm{c}}<1100 \mathrm{~kg} / \mathrm{cm}^{2}$ 
Where $\mathrm{f}_{\mathrm{c}}$ : the 28 -days cube compressive strength $\left(\mathrm{kg} / \mathrm{cm}^{2}\right)$ of concrete and $\mathrm{K}$ : the permeability coefficient $(\mathrm{cm} / \mathrm{sec})$.

Figure 9 shows the experimental and theoretical relationship between the water permeability and compressive strength of concrete. It is obvious that the permeability of concrete is inversely proportional to its strength. This is due to that by increasing the strength of concrete, the microstructure of the cement matrix will be denser and voids will decrease. Furthermore, because of the absence of the connections between the capillary pores in VHSC and UHSC, the permeability of such types of concretes were very small and may be zero and thus such types of concrete are suitable for using in hydraulic structures and water tanks.

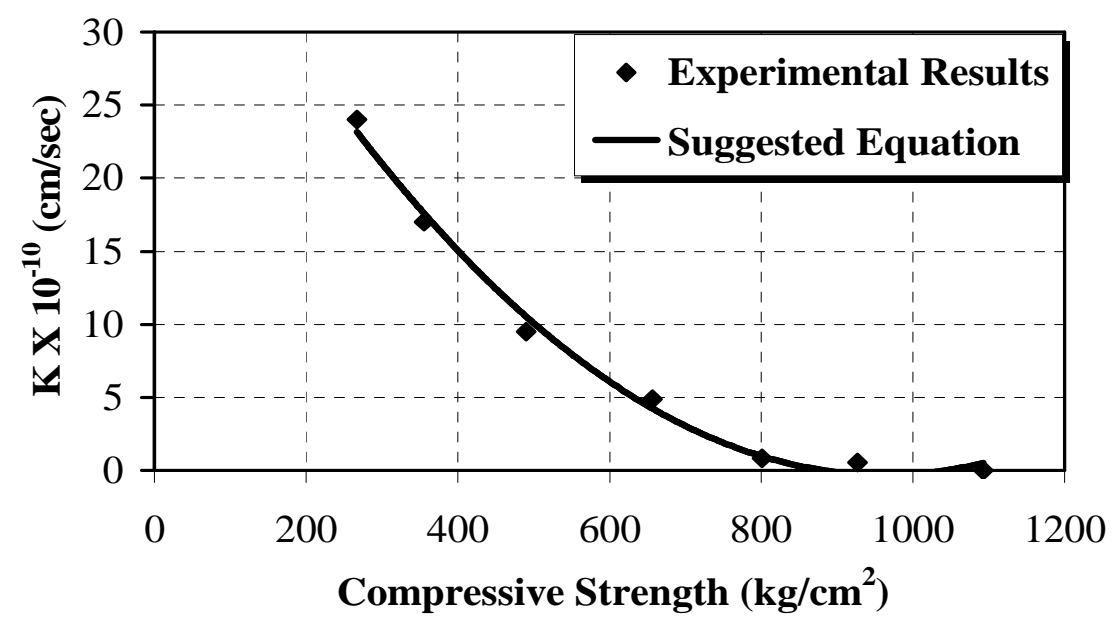

Fig. 9. Relationship between the permeability and compressive strength of concrete

\subsection{Water absorption}

The amount of water absorbed in a concrete is indicative of its permeable pores, which implies that the steel of concrete shall stain. The water absorption of concrete mixes is shown in fig. 10. It was found that at the same water content and curing technique, the water absorption of concrete decreases by increasing the content of cement. It decreased by $15.8 \%$ by increasing cement content from 350 to $400 \mathrm{~kg} / \mathrm{m}^{3}$ in the comparison between mix 1 and 2. As expected, the water absorption is proportional to w/c ratio; the higher w/c ratio, the higher the absorption. Comparing mix 2 and 3, it is clear that the absorption decreased by $13.3 \%$ by decreasing w/c ratio from 0.5 to 0.4 . The addition of silica fume to concrete significantly decreases the absorption of water. Water absorption decreased by $20.6 \%$ by adding $10 \%$ silica fume (mix 3 and 4 ). This is due the transformation of larger pores into finer pores as a result of the filler effect and pozzolanic reaction of silica fume, thus providing a barrier against water penetration. For the same concrete mix, steam curing decreases the absorption as compared to standard moist curing. The absorption decreased by $25.6 \%$ by using steam curing instead of standard moist curing (mix 5 and 6). 


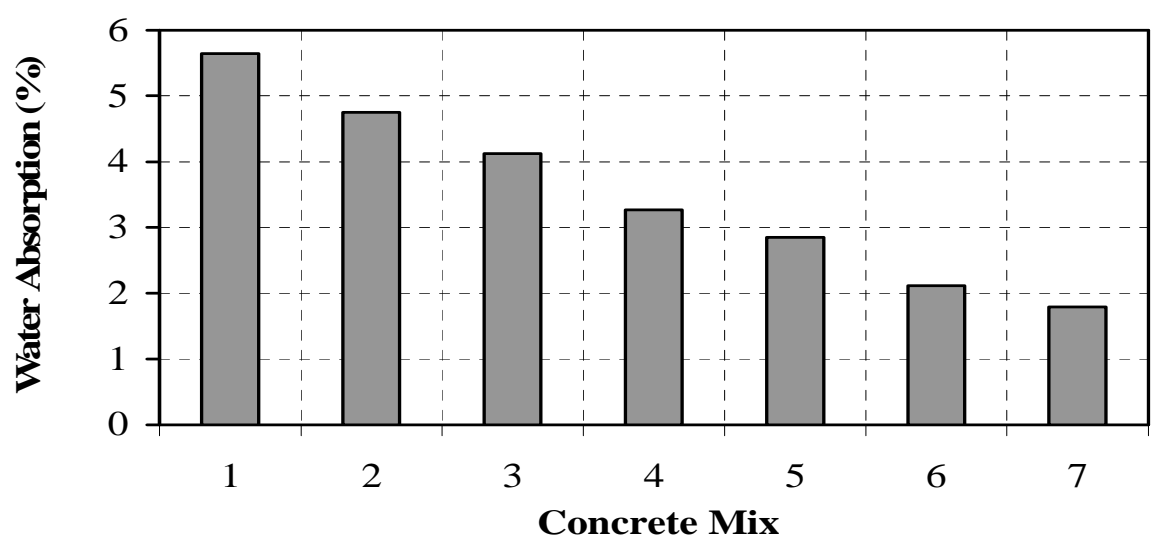

Fig. 10. Water absorption resistance of concrete mixes

A mathematical relationship between the water absorption and compressive strength of concrete was suggested as follows:
$\mathrm{A}=\mathbf{- 2 . 6 9 9 8} \operatorname{Ln}\left(f_{c}\right)+\mathbf{2 0 . 7 2 9}$
for $265 \mathrm{~kg} / \mathrm{cm}^{2}<\mathrm{f}_{\mathrm{c}}<1100 \mathrm{~kg} / \mathrm{cm}^{2}$

Where $\mathrm{f}_{\mathrm{c}}$ : the 28 -days cube compressive strength $\left(\mathrm{kg} / \mathrm{cm}^{2}\right)$ of concrete and $\mathrm{A}$ : the absorption of concrete (\%).

Figure 11 shows the relationship between the water absorption and compressive strength of concrete. It is obvious that water absorption of concrete is inversely proportional to its strength. This is expected that usually by increasing the strength of concrete, the microstructure of the cement matrix will be more compact and void structure will be extremely low. The absorption of HSC decreased by about $29 \%$ compared to NSC, and for VHSC it decreased by about 52\% and 33\% compared to NSC and HSC, respectively. Furthermore, the absorption of UHSC decreased by about $66 \%, 52 \%$ and $28 \%$ compared to NSC, HSC and VHSC, respectively.

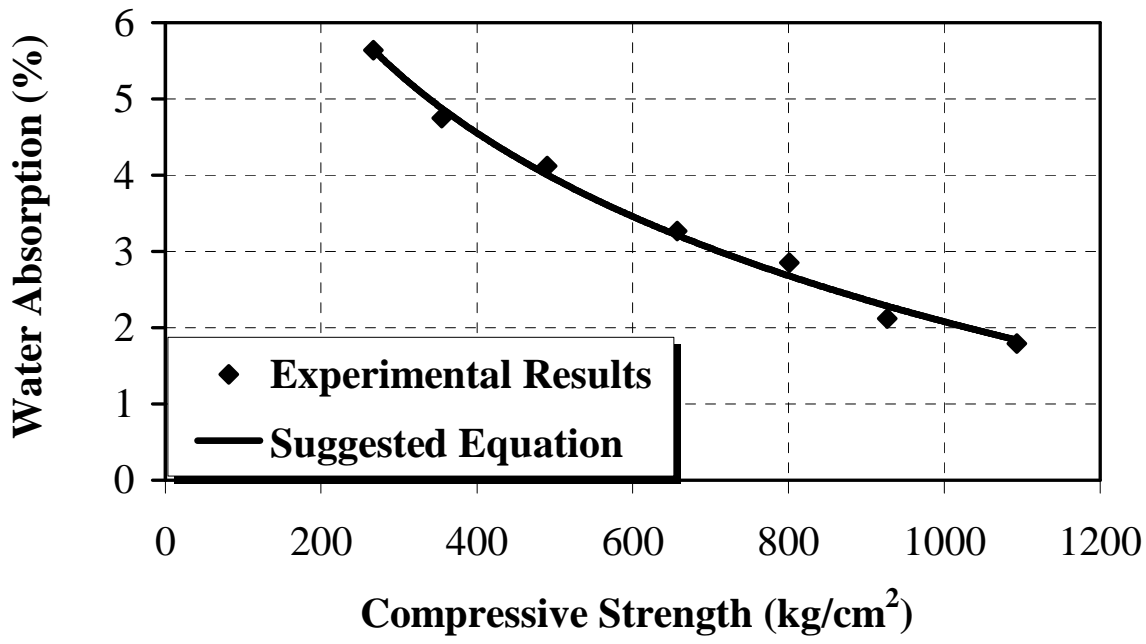

Fig. 11. Relationship between the absorption and compressive strength of concrete 


\subsection{Abrasion resistance}

Abrasion is the wearing due to repeated rubbing, and friction of objects on concrete surface. Abrasion resistance of concrete is of crucial importance in pavements, floors, and hydraulic structures. The loss of specimen thickness by abrasion was used to express the abrasion resistance of concrete. Results of abrasion resistance of concrete mixes are shown in fig. 12. It was found that in general, the abrasion of concrete, as measured by the loss of thickness of the specimens, was lower than the abrasion limits specified in ESS No. 269/2003 for cement tiles (i.e., not more than $5.2 \mathrm{~mm}$ for normal service and $3 \mathrm{~mm}$ for heavy service). Therefore, the concrete mixes even normal strength concrete could be considered as a high abrasion resistant material. The abrasion of concrete decreased by $7.8 \%$ by increasing the content of cement from 350 to $400 \mathrm{~kg} / \mathrm{cm}^{2}$ in the comparison between concrete mix 1 and 2 . The abrasion of concrete decreases significantly by decreasing $\mathrm{w} / \mathrm{c}$ ratio in the mix. The abrasion of concrete decreased about $13 \%$ by decreasing w/c ratio from 0.50 to 0.40 (mixes 2 and 3). Comparing the abrasion of mix 3 and 4 , it can be stated that the addition of silica fume to concrete decreases the concrete abrasion by $6.1 \%$. The abrasion decreased by $10.2 \%$ by using steam curing instead of standard moist curing in the comparison between mix 5 and 6 . The most significant factor influencing the abrasion resistance of concrete is the $\mathrm{w} / \mathrm{c}$ ratio of the mix.

A mathematical relationship between the abrasion resistance and compressive strength of concrete was suggested as follows:
$\mathrm{X}=-2 \mathrm{E}-07 f_{c}{ }^{2}-0.0006 f_{c}+1.5559$
for $265 \mathrm{~kg} / \mathrm{cm}^{2}<\mathrm{f}_{\mathrm{c}}<1100 \mathrm{~kg} / \mathrm{cm}^{2}$

Where $\mathrm{f}_{\mathrm{c}}$ : the 28-days cube compressive strength $\left(\mathrm{kg} / \mathrm{cm}^{2}\right)$ of concrete and $\mathrm{X}$ : the loss of concrete thickness (mm).

Figure 13 shows the relationship between abrasion resistance and compressive strength of concrete. It is clear that in general, the abrasion resistance of concrete increases by increasing its strength. The abrasion resistance of HSC increased by about $19 \%$ compared to NSC, and it increased by about 32\% and 16\% for VHSC compared to NSC and HSC, respectively. Furthermore, the abrasion resistance of UHSC increased by about 55\%, 44\% and 33\% compared to NSC, HSC and VHSC, respectively.

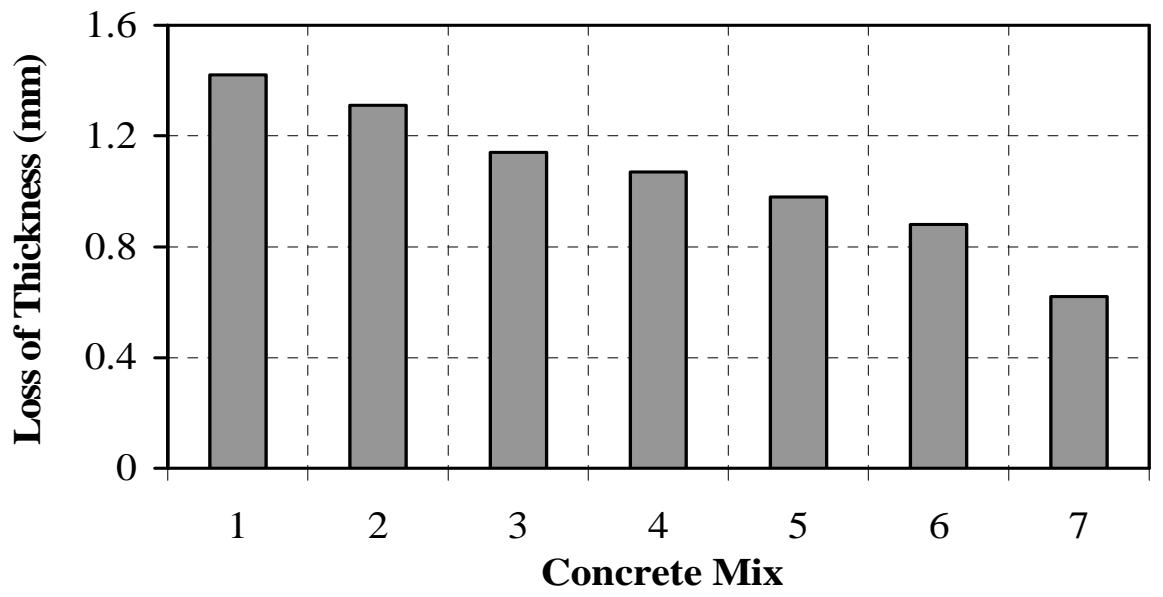

Fig. 12. Abrasion resistance of concrete mixes 


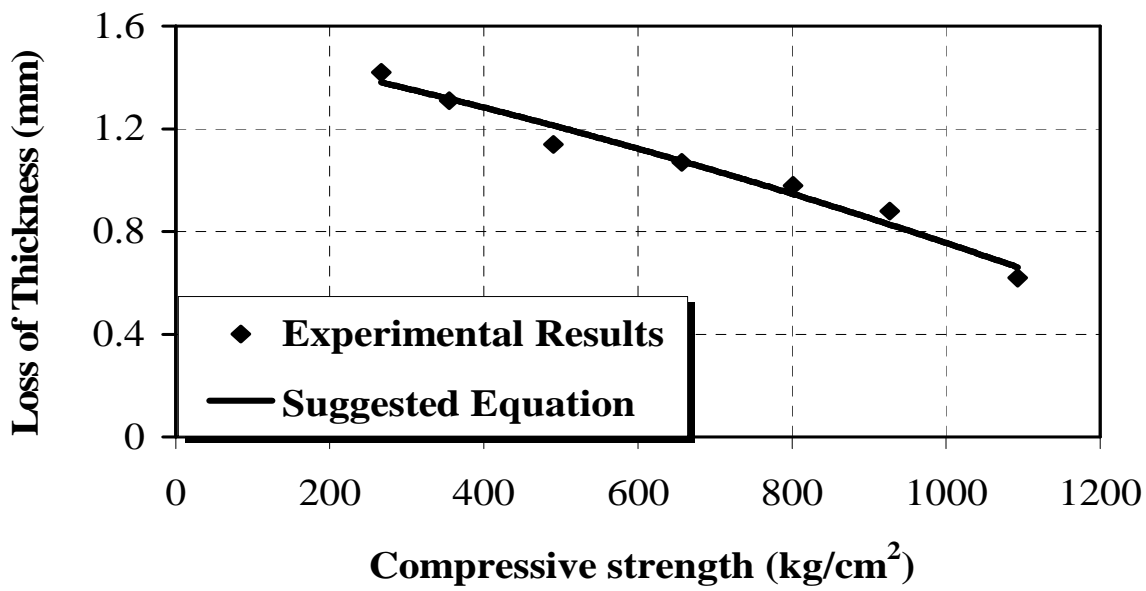

Fig. 13. Relationship between abrasion resistance and compressive strength of concrete

\section{CONCLUSION}

1. Water-cement ratio was found to be the overriding factor affecting the compressive strength and abrasion resistance of concrete, while the addition of silica fume governs the tensile strength and permeability of concrete. Steam curing is most important factor affecting the flexural strength and water absorption of concrete.

2. Water-cement ratio and mineral admixtures such as silica fume are the most important parameters for producing very high strength and ultra high strength concretes.

3. The ratio between the splitting tensile strength to compressive strength as well as that between the flexural strength to compressive strength of concrete are not unique but depend on compressive strength; the higher the compressive strength, the lower the ratios.

4. By increasing the compressive strength of concrete, other mechanical properties as well some durability-related properties such as abrasion resistance, water absorption and permeability are improved.

5. The suggested equation for predicting the splitting tensile strength of concrete based on its compressive strength is very close to the ACI equation. On the other hand, the suggested equation for predicting the flexural strength of concrete based on its compressive strength overestimates the flexural strength compared with the ACI equation.

6. The permeability and water absorption of very high strength concrete and ultra high strength concrete were very small, thus such types of concrete are suitable for hydraulic structures and water tanks.

7. It is possible to produce ultra high strength concrete, with compressive strength in excess of $1000 \mathrm{~kg} / \mathrm{cm}^{2}$ after 28-days of curing using local materials if these materials are carefully selected and properly mixed, taking into account the content of cement, w/c ratio, using of chemical and mineral admixtures, and curing technique. 
8. The mechanical properties and durability-related properties of concrete with compressive strength in the range 265 to $1100 \mathrm{~kg} / \mathrm{cm}^{2}$ can be predicted using the suggested equations.

\section{REFERENCES}

[1] Raju N. K., "Design of concrete mixes", Fourth Edition, 2004, ISBN 81-2390218-2, CBS Publishers \& Distributers, India.

[2] Alois Frommenwiler, "New Generation of Superplasticizers for High Performance Concrete (HPC)", MBT Holding, Switzerland, 2000. 3. F. Puertas, H. Santos.

[3] ACI committee 363, "State of the art report on high strength concrete", American Concrete Institute Journal, July-August, 1992.

[4] Maiti S. C., Agarwal R. K. and Kumar R.,"Concrete mix proportioning", The Indian Concrete Journal, December 2006, pp. 23-26.

[5] Hela R., Ondracek M. and Sedlmajer M., "Using of secondary raw materials for production of high performance concrete with high and ultra high strengths", Brno University of Technology, Faculty of Civil Engineering.

[6] Arafa M., Shihada S. and Karmout M., "Mechanical properties of ultra high performance concrete produced in the Gaza Strip", Asian Journal of Materials Science, Vol. 2, 2010, pp. 1-12.

[7] "Concrete in practice: what, why \& how? - CIP 33, High strength concrete", http://www.nrmca.org/aboutconcrete/cips/33p.pdf.

[8] Yazıcı H., "The effect of curing conditions on compressive strength of ultra high strength concrete with high volume mineral admixtures", Building and Environment, Vol. 42, 2007, pp. 2083-2089.

[9] Graybeal B. A. and Hartmann J. L., "Ultra-high performance concrete material properties", Transportation Research Board Conference, November 15, 2002.

[10] C. L. Page and M. M. Page, "Durability of concrete and cement composites", http://openlibrary.org/books/OL11560540M/Durability of concrete and cemen t com

[11] Sabir B. B., "Mechanical properties and frost resistance of silica fume concrete", Cement and Concrete Composites, 1997, Vol. 19, pp. 285-294.

[12] Zain M. F. M., Safiuddin M. d. and Mahmud H., "Development of high performance concrete using silica fume at relatively high water-binder ratios", Cement and Concrete Research, 2000, pp. 1501-1505.

[13] Yasmin A., "An analysis of practices for concrete bridge deck durability", Department of Civil engineering, Texas Tech. University, 2000.

[14] Büyüköztürk O. and Lau D., "High performance concrete: fundamentals and application", Department of Civil and Environmental Engineering, Massachusetts Institute of Technology, Cambridge. 


\section{سلوك ومتانة الخرسانة عالية وفائقة المقاومة المصنعة باستخدام المواد المحلية}

فى العقود الاخيرة تطور مجال صناعة الخرسانة نطورا سريعا و كبيرا؛ حيث ظهرت رتب جديدة من الخرسانات (عالية، عالية جدا، و فائقة المقاومة) و تحولت من الاختبارات المعمليه الى التطبيق العملي و تزايد استخدامها حيث اصبحت تحل محل الخرسانة عادية المقاومة فى العديد من التطبيقات الانشائية. و بالرغم من تعيين الخواص الميكانيكية و التحمل مع الزمن للخرسانة عادية المقاومة الا ان تلك الخواص و ولى العلاقات بينها و بين مقاومة الضغط لم يتم تعيينها بوضوح للانواع الجديدة من الخرسانات. يتم فى هذا البحث انتاج خرسانات برثب مختلفة بحيث تتراوح مقاومة الضغط بين 250 - 1000 كجم/سم2 باستخدام المواد المحلية و تعبين خواصها الميكانيكية و تحملها مع الزمن. بالاضافة الى ذلك يتم استتتاج العلاقات الرياضية بين مقاومة الضغط و الخواص المختلفة للخرسانات المنتجة باستخدام التحليل الاحصائى. اوضحت النتائج امكانية انتاج خرسانات بمقاومة ضغط تتجاوز 1000 كجم/سم2 باستخدام المواد المحلية فى بلى مصر، كما يمكن استخدام المعادلات الرياضية المقترحة لاستتناج خواص الخرسانة بناءا على مقاومتها 